\title{
MINIMUM STANDARD OF TREATMENT OF ALIENS, FAIR AND EQUITABLE TREATMENT OF FOREIGN INVESTORS, CUSTOMARY INTERNATIONAL LAW AND THE DIALLO CASE BEFORE THE INTERNATIONAL COURT OF JUSTICE
}

\section{Estándar mínimo de protección de extranjeros, trato justo y equitativo de inversionistas, y la costumbre internacional en el caso Diallo ante la corte internacional de justicia.}

ABSTRACT
$\begin{aligned} & \text { The Diallo Case before the International Court of Justice } \\ & \text { seems to offer a unique opportunity to declare both the } \\ & \text { minimum standard of treatment of aliens and the fair and } \\ & \text { equitable treatment standard as customary international } \\ & \text { law. This article analyzes the set of factors in play } \\ & \text { simultaneously in public international law and in } \\ & \text { international investment law that supports such } \\ & \text { expectations. However, the article alsopresents the other set } \\ & \text { of factors in these fields that does notprovide strong support } \\ & \text { for the said hopes. The article concludes, first, that the } \\ & \text { Diallo Case could give the long-awaited clarification of the } \\ & \text { content of the minimum standard of treatment of aliens } \\ & \text { with regard to foreign investors; and, second, that it is } \\ & \text { unlikely that the fair and equitable treatment standardwill } \\ & \text { end up receiving the official status of customary } \\ & \text { international law. } \\ & \text { DESCRIPTORS: Foreign investors; minimum } \\ & \text { standard of treatment; fair and equitable treatment } \\ & \text { standard; customary international law. }\end{aligned}$
ing

States and foreign investors should closely follow the Case Concerning Abmadou Sadio Diallo (Republic of
Alberto Alvarez Jiménez *

\section{SINTESIS}

El caso Diallo que cursa en la actualidad ante la Corte Internacional de Justicia parecería ofrecer la oportunidad perfecta para la declaración de los estándares de trato minimo de extranjeros y de trato justo y equitativo como costumbre internacional. El articulo analiza el conjunto de factores presentes boy en el derecho publico internacional y en el derecho de las inversiones que justificaría la mencionada posibilidad. Sin embargo, el articulo también ilustra la otra serie de elementos en estas áreas jurídicas que se oponen a tal resultado. El articulo concluye, primero, que el caso Diallo constituye una oportunidad para la muy esperada clarificación del contenido del estándar del trato mínimo debido por los Estados a los ciudadanos o empresas extranjeros; y, segundo, que es improbable que el estándar de trato justo y equitativo sea elevado al rango de costumbre internacional.

DESCRIPTORES: Inversionistas extranjeros; estándar de tratamiento mínimo de extranjeros; estándar de trato justo y equitativo; costumbre internacional

Guinea v. Democratic Republic of the Congo) before the International Court of Justice (ICJ). In this case,

* $\quad \mathrm{PhD}$. Universidad de Ottawa. Académico y consultor internacional. El presente articulo apareció publicado en el JOURNAL OF WORLD INVESTMENT AND TRADE. Vol 19. No 1.2008.

1 The concept of diplomatic protection is a rule of customary international law, and it was Emmerich de Vattel who first defined it in 1758 when he stated that "whoever ill-treats a citizen indirectly injures the State, which must protect that citizen." Emmerich de Vattel, The Law of Nations or the Principles of Natural Law Applied to the Conduct and to the Affairs of Nations and Sovereigns, Vol III (Washington: Carnegie Institution, 1916) at 136.

A contemporary notion is provided in Article 1 of the Draft Articles on Diplomatic Protection of the International Law Commission, according to which:

[D]iplomatic protection consists of the invocation by a State, through diplomatic action or other means of peaceful settlement, of the responsibility of another State for an injury caused by an internationally wrongful act of that State to a natural or legal person that is a national of the former State with a view to the implementation of such responsibility. 
Guinea is exercising its diplomatic protection $^{1}$ on behalf of a Guinean businessman, Mr. Diallo, claiming that the Democratic Republic of Congo has violated "the principle that aliens should be treated in accordance with a 'minimum standard of civilization.",2 This claim could thus be seen as offering counsellors for foreign investors the exceptional opportunity that they have been waiting for: that of proffering the conclusive declaration, as customary international law, of the minimum standard of treatment of aliens, or better still, for its identification with the fair and equitable treatment standard on the basis of the wide inclusion of the latter in bilateral investment treaties (BITs) by States of all types. In other words, the facts and claims of the Diallo case would seem to offer a unique opportunity to declare both the minimum standard of treatment of aliens and the fair and equitable treatment standard as customary international law.

A set of factors in play simultaneously in public international law and in international investment law, along with the particularities of the Diallo dispute, could support such expectations. First, contrary to what some States have contemplated in bilateral and regional treaties, the minimum standard of treatment of aliens is an elusive concept in public international law, whose nature and content, or contents, remain to be determined. ${ }^{3}$ Second, such uncertainties could eventually lead the Court to resort to the widespread consecration of the fair and equitable treatment standard in BITs as the way to solve the difficulties in determining the status and content of the minimum standard of treatment of aliens under international law in the Diallo dispute, which involves a foreign investor. Such a course would be possible, since even former judges of the Court and well-known arbitrators, such as Stephen Schwebel, as well as international arbitration tribunals have suggested that the standard of fair and equitable treatment, by being embodied in almost two thousand bilateral investment agreements, has

2 International Law Commission, Draft Articles on Diplomatic Protection with Commentaries, 2006. available at http://www.un.org/law/ilc/. [hereinafterILCCommentaries]. International Court of Justice. Case Concerning Abmadou Sadio Diallo. (Republic of Guinea v. Democratic Republic of the Congo, Preliminary Objections of 24 May 2007. 1\& 28. available at http:// www.icj-cij.org/docket/files/70/6503.pdf [hereinafter Diallo]. For a detailed analysis of this decision, see Alberto Alvarez-Jiménez, Foreign Investors, Diplomatic Protection and the International Court of Justice's Decision on Preliminary Objections in the Diallo Case 33 NORTH CAROLINA JOURNAL OF INTERNATIONAL LAW AND COMMERCIAL REGULATION (forthcoming).

The date of the judgment on the merits of the case is uncertain. The ICJ has no deadlines to render its judgments, and the proceedings are still at an early stage, so the judgment on the merits may not be expected soon. An idea of how much time it may take may be gleaned from the fact that the Application before the Court was filed by Guinea in 1998, and the Decision on Preliminary Objections was handed down almost nine years later.

3 See Part II.A below for a detailed assessment of the elusiveness of the minimum standard of treatment of aliens in international law: 
reached the status of customary international law. ${ }^{4}$ This could pave the way for its identification with the minimum standard of treatment of aliens in the Diallo case. And third, because, to some, the Court has loosened the requirements for the declaration of customary international law, which could make it easier to declare the fair and equitable treatment standard a rule of such character. In sum, important factors seem to be in place for having hopes for such declarations by the ICJ.

However, the present author is of the view that, while this set of favourable elements indeed provides grounds for such expectations, the revival by the ICJ of its strict jurisprudence regarding international customary law precisely in the Decision on Preliminary objections in the Diallo case, coupled with a new approach in certain important States to grant foreign investors lower, not higher, levels of protection, does not provide strong support for the expectation that the ICJ could offer in Diallo the result that foreign investors may be desiring. In other words, the fair and equitable treatment standard does not meet the threshold of the ICJ's revived strict approach to customary international law, and therefore, there would be no reason to use it to

4 Commenting on the inclusion of the fair and equitable treatment standard in multiple BITs, Schwebel says:

The phenomenon of how and when provisions of treaties binding only on parties may seep into general international law and thus binding the international community as a whole is subtle and elusive. It is nevertheless a process known to international law. It is a process of which some 2,200 bilateral investment treaties are the contemporary exemplar.

Stephen M. Schwebel, The Reshaping of the International Law of Foreign Investment by Concordant Bilateral Investment Treaties in Steve Charnovitz, Debra P. Steger and Peter Van den Bossche, eds., LAW IN THE SERVICE OF HUMAN DIGNITY. ESSAYS IN HONOUR OF FLORENTINO FELICIANO (Cambridge: Cambridge University Press, 2005) 241 $244-5$.

It is also important to mention that the transformation of bilateral treaties into customary international law is not only a question of the number of bilateral treaties involved. Even a single bilateral treaty can reach such status, as was the case of rules of the Treaty of Washington between Great Britain and the United States establishing the arbitration of the Alabama claims, signed in 1871. This treaty established that neutral governments had to prevent the equipping of belligerent vessels, preclude the use of their territory by belligerents, and surveil in order to prevent violations of these duties. In 1907, when the Convention No XIII regarding the Rights and Obligations of Neutral Powers in Naval War was adopted, it was accepted that the rules of the Treaty of Washington had become customary international law. See in this regard, R.R. Baxter, Treaties as Customs in RECUEIL DES COURS. COLLECTED COURSES OF THE HAGUE ACADEMY OF INTERNATIONAL LAW. 1970. I. TOME 129. (Leyden: A.W. Sijthoff, 1971) 3179.

5 Provided that Guinea fully pursues this claim, the possibility mentioned in the text exists as a matter of procedure, given that Guinea is claiming a violation of the "the principle that aliens should be treated in accordance with a 'minimum standard of civilization,"' and it is for the Court to determine the content of the standard. In this connection, it is important to mention that the ICJ has recognized for itself the freedom to develop its own argumentation. For instance, in its judgment in Fisheries Jurisdiction Case (Federal Republicf Germany v. Iceland), the ICJ stated:

The Court ... as an international judicial organ, is deemed to take judicial notice of international law, and is therefore required in a case falling under Article 53 of the Statute, as in any other case, to consider on its own initiative all rules of international law which may be relevant to the settlement of the dispute. It being the duty of the Court itself to ascertain and apply the relevant law in the given circumstances of the case, the burden of establishing or proving rules of international law cannot be imposed upon any of the parties, for the law lies within the judicial knowledge of the Court.

International Court of Justice. Fisheries Jurisdiction Case (Federal Republicf Germany v. Iceland), Judgment of 25 July 1974. [1974] I.C.J. Rep. 9 18, quoted in Case Concerning Military and Paramilitary Activities In And Against Nicaragua. (Nicaragua v. United States of America), Judgment of 27 June 1986. [1986] I.C.J. Rep. 14 29. [hereinafter Nicaragud]. 
ascertain whether the DRC violated the "the principle that aliens should be treated in accordance with a "minimum standard of civilization" in relation to Mr. Diallo's rights as a shareholder.

Before delving into the demonstration of this proposition, it is important to clarify that the purpose of this paper is not to predict the result of the Diallo dispute, a case that has not even been pleaded before the Court, but a much narrower one: to illustrate, first, the reasons for investors' high expectation in this case, and second, to show why these expectations may be excessive in light of the Court's overall jurisprudence regarding customary international law and of the recent approach by States as to the level of protection of foreign investors. Although the Diallo dispute will be an important decision for them in any case, the significance may not be the one they desire.

This paper is divided into four parts. The first part presents the facts of the Diallo dispute and the aspects of the dispute that the ICJ will deal with in its decision on the merits. The second part will present the reasons, based on both public international law and foreign investment law, supporting investors' expectations of a favourable pronouncement of the ICJ in the judgment on the merits of the Diallo case. The third section will illustrate the factors also present in these two fields of international law and in the jurisprudence of the ICJ that run against such expectations. The fourth part presents the conclusions of the paper.

\section{THE FACTS OF THE DIALLO DISPUTE}

The facts of the Diallo dispute before the ICJ can be summarized as follows: Ahmadou Sadio Diallo is a Guinean businessman who lived in the Democratic Republic of Congo (DRC), known as Zaire from 1971 to 1997, for 32 years. ${ }^{6}$ He settled there in 1964, and ten years later he founded a company named Africom-Zaire in the DRC and became its manager. ${ }^{7}$ In 1979, Africom-Zaire (Africom) along with two partners created AfricontainersZaire (Africontainers). However, in 1980, the two partners withdrew, and its capital was then owned $60 \%$ by Africom and $40 \%$ by Mr. Diallo, who also became its manager.

Both Africom and Africontainers started having problems with major 
Congolese public institutions and private companies in the 1980s. Africom has debts recognized by the DRC for contracts celebrated and performed between 1983 and 1986, and it had a dispute with a private company called Plantation Lever au Zaire.' Africontainers, for its part, had controversies with Zaire Shell, Zaire Mobil Oil and the Congolese Office National des Transport and Générale des Carrières et des Mines. ${ }^{10}$ Both Africom and Africontainers started judicial proceedings to resolve their disputes, but they remain unresolved to date. ${ }^{11}$ Both companies are claiming damages against Congolese public entities that amount to USD 36 billion, an amount that is three times the DRC's foreign debt. ${ }^{12}$

The relations between Mr. Diallo and the above-mentioned private companies kept deteriorating, and in 1995 the companies asked for Congolese government intervention "to warn the courts and tribunals about Mr. Amadou Sadio Diallo's conduct in his campaign to destabilize commercial companies." ${ }^{, 13}$ On October 31, 1995, the Prime Minister of Zaire, today the DRC, ordered the expulsion of Mr. Diallo on the grounds that his "presence and conduct have breached public order in Zaire, especially in the economic, financial and monetary areas, and continue to do so." ${ }^{, 4}$ Prior to his expulsion, Mr. Diallo had been arrested and imprisoned. ${ }^{15}$

Guinea argues that Mr. Diallo's detention and expulsion have violated the Vienna Convention on Consular Relations ${ }^{16}$ and that it seeks to exercise its right to diplomatic protection of Mr. Diallo's rights as an individual and as a shareholder of Africom and Africontainers, specifically, his rights to oversee, control and manage the companies. Guinea also sought to exercise its

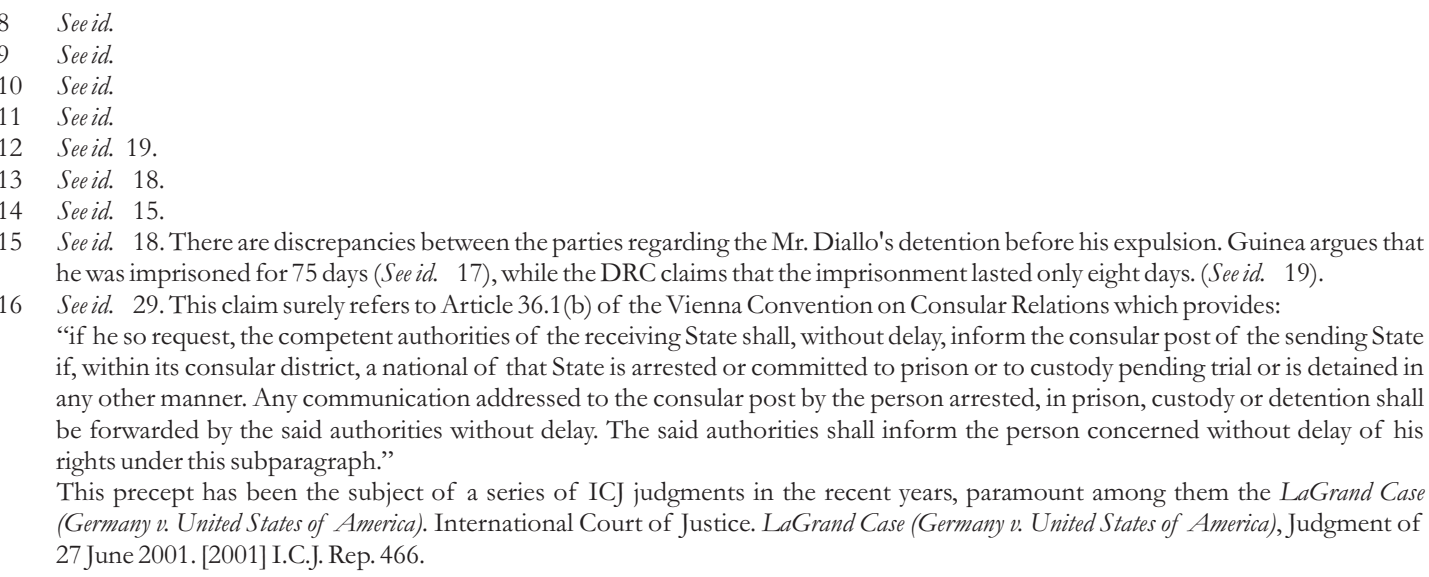
if, within its consular district, a national of that State is arrested or committed to prison or to custody pending trial or is detained in any other manner. Any communication addressed to the consular post by the person arrested, in prison, custody or detention shall be forwarded by the said authorities without delay. The said authorities shall inform the person concerned without delay of his rights under this subparagraph."

This precept has been the subject of a series of ICJ judgments in the recent years, paramount among them the LaGrand Case (Germany v. United States of America). International Court of Justice. LaGrand Case (Germany v. United States of America), Judgment of 27 June 2001. [2001] I.C.J. Rep. 466. 
right to diplomatic protection, by substitution, of these companies, in order to recover the debts owed to them. According to Guinea, ${ }^{17}$ the DRC has violated the Vienna Convention on Consular Relations; ${ }^{18}$ the Universal Declaration of Human Rights of December 10, 1948; and the International Covenant on Civil and Political Rights of December 19, 1966. Finally, Guinea claims that the DRC failed to grant Mr. Diallo treatment according to "a minimum standard of civilization.", 19

In response to these claims, the DRC presented two preliminary objections: first, that Mr. Diallo had not exhausted the local remedies available to him, and second, that Guinea lacked standing to seek the diplomatic protection of Africom and Africontainers, since these companies were not incorporated under its laws. ${ }^{20}$ The ICJ rejected the first objection ${ }^{21}$ and upheld the second one in its decision on preliminary objections. ${ }^{22}$ Therefore, the judgment on the merits will deal with, among other claims not relevant for the purpose of this paper, whether or not Mr. Diallo's rights as an investor were violated by the DRC. If they were, the implication would be, on the basis of the notion of diplomatic protection, that the DRC had breached international obligations owed to Guinea.

Having presented the facts of the Diallo case and of its claim of violation of the minimum standard of civilization by the DRC, this paper proceeds to assess the reasons that could support foreign investors' positive expectations regarding the ICJ's judgment on the merits in this case.

\section{FOREIGN INVESTORS' REASONS FOR HOPE IN THE DIALLO CASE BEFORE THE ICJ}

A complete perspective of the interplay between public international law and BITs would allow investors to place certain hopes on a positive jurisprudence in the Diallo case. First, the nature and content of the minimum standard of treatment of aliens is not defined in international law. Second, such uncertainty could offer the ICJ the

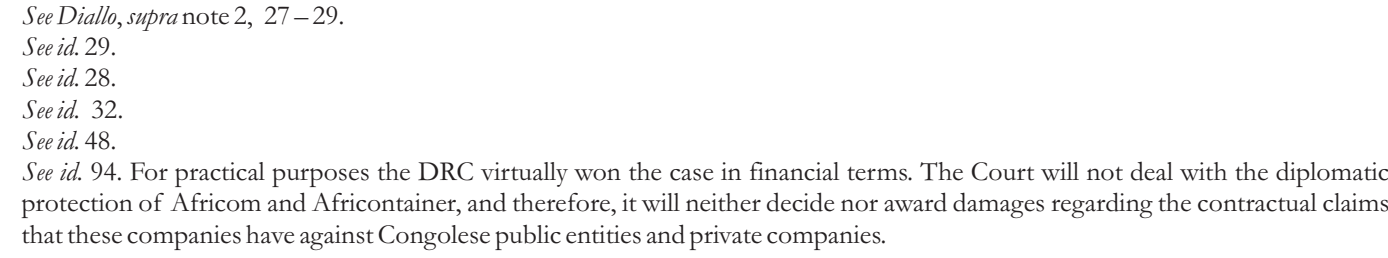

See id. 94. For practical purposes the DRC virtually won the case in financial terms. The Court will not deal with the diplomatic protection of Africom and Africontainer, and therefore, it will neither decide nor award damages regarding the contractual claims that these companies have against Congolese public entities and private companies. 
possibility of relying on the fair and equitable treatment standard to determine the content and nature of the minimum standard of aliens in the Diallo case, which involves a foreign investor. Such reliance would be possible on the basis of the declaration of the former standard as customary international law, since it has been included in more than two thousands BITs signed by States of all kinds and at all stages of development. And third, the possibility of elevating the standard of fair and equitable treatment to the status of customary international law is at least hypothetically possible, because the ICJ has developed a flexible approach to the declaration of international norms of this character.

\section{A. THE UNCERTAINTIES SURROUNDING THE MINIMUM STANDARD OF TREATMENT OF ALIENS UNDER INTERNATIONAL}

\section{LAW}

1. THE INTERNATIONAL LAW COMMISSION'S ELUSIVE APPROACH REGARDING THE MINIMUM STANDARD OF TREATMENT OF ALIENS.
Apparently, the minimum standard of treatment of aliens has a secure and clear place in international law, since the ICJ recognized it in its judgment in the Case Concerning the Barcelona Traction Light and Power Company Limited (Belgium v. Spain), Second Phase when it said in passing that

[W] hen a State admits into its territory foreign investment or foreign nationals it is ... bound to extend to them the protection of the law. However, it does not thereby become an insurer of that part of another State's wealth which these investments represent.... The real question is whether a right has been violated, which right could only be the right of the State to have its nationals enjoy a certain treatment guaranteed by general international law, in the absence of a treaty applicable to the particular case....

However, the reference to the standard, although it more or less recognizes its existence as a matter of general international law, says nothing about its content, even at the highest level of generality, or regarding its nature as either a general principle or as a customary rule of international

23 International Court of Justice. Case Concerning the Barcelona Traction Light and Power Company Limited (Belgium v. Spain), Second Phase, Judgment of 5 February 1970. [1970] I.C.J. Rep. 387. [hereinafter Barcelona Traction]. 
law. The uncertainty around the minimum standard of treatment of aliens under international law increases once one looks at the other readily available source for identification of international customs and their content, the works of the International Law Commission (ILC).

The ILC has been unable to deal with the minimum standard of treatment of aliens and has avoided it for decades, which is telling evidence of the difficulty of defining the content of the standard. In effect, in 1957, the Special Rapporteur, GarciaAmador, tried to link the minimum standard of treatment of aliens with the new international human rights law produced after World War II. However, the Commission did not support this approach, and in 1963, decided that

it was desirable to carry out a general study of the subject [of State Responsibility], taking care not to confuse the definition of the rules relating to responsibility with that of the rules of international lawand in particular those relating to the treatment of aliens-the breach of which can give rise to responsibility. ${ }^{24}$

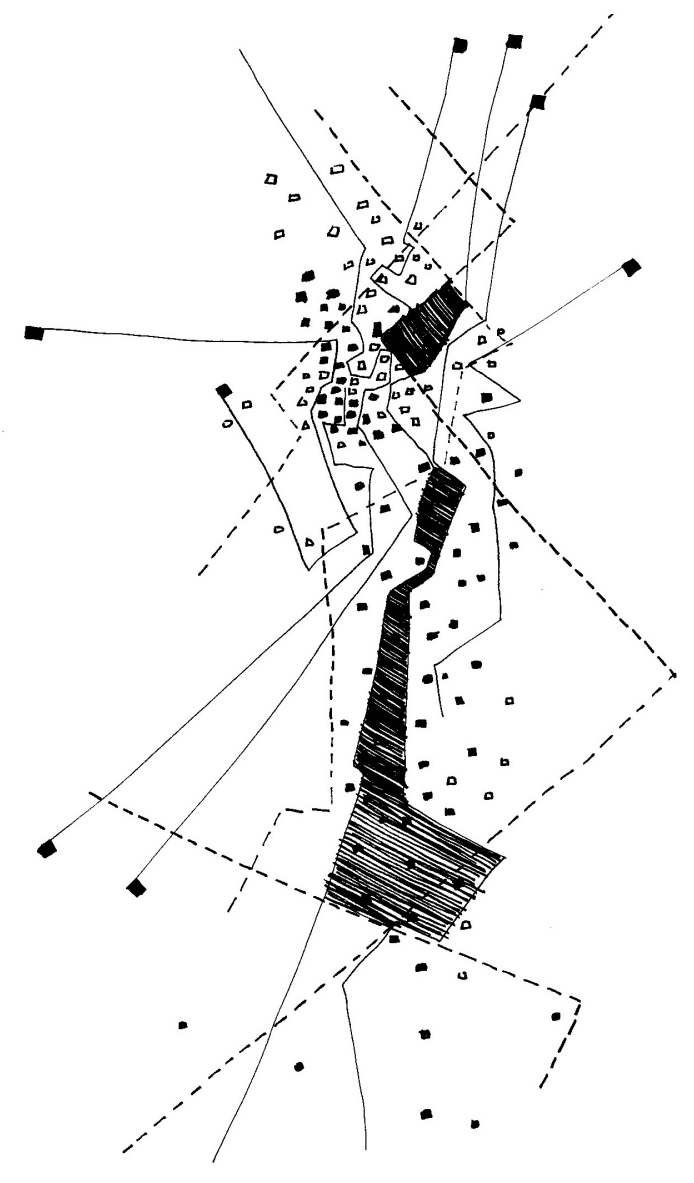

Not long ago, in 2006, the ILC did the same when it released its Draft Articles on Diplomatic Protection. The ILC stated:

Diplomatic protection belongs to the subject of 'Treatment of Aliens'. No attempt is made, however, to deal with the primary rules on this subject - that is, the rules governing the treatment of the person and property of aliens, breach of which gives

24 For a detailed analysis of the handling, of lack of it, of the ILC of the minimum standard of treatment of aliens, see Richard B. Lillich, The Current Status of the Law of State Responsibility for Injuries to Aliens in Richar B. Lillich, ed., INTERNATIONAL LAW OF STATE RESPONSIBILITY FOR INJURIES TO ALIENS (Charlottesville: University Press of Virginia, 1983) 120. 
rise to responsibility to the State of nationality of the injured person. Instead the present draft articles are confined to secondary rules only - that is, the rules that relate to the conditions that must be met for the bringing of a claim for diplomatic protection....

The ILC's decision is simply the most telling proof of the fact that the content or contents of the standard are not clear, ${ }^{26}$ nor is the nature of the standard evident as a general principle of law or as customary international law. The standard exists, as evidenced by the ICJ's mention of it in Barcelona Traction, but its content, which determines when the actions or omissions of a State with regard to an alien fall below this minimum standard, is altogether uncertain, and so is its nature. ${ }^{27}$

\section{THE MINIMUM STANDARD OF TREATMENT OF ALIENS, BITS AND INVESTOR/STATE TRIBUNALS}

Despite the fact that, as has been illustrated, the nature and content of the minimum standard of treatment of aliens have not been determined under general public international law, some regional and bilateral investment treaties contemplate the standard as if it were readily applicable. Prominent among them is NAFTA Article 1105.1 as interpreted by the Free Trade Commission, which provides that:

Each Party shall accord to investments of investors of another Party treatment in accordance with international law, including fair and equitable treatment and full protection and security.

25 ILC Commentaries, supra note 1 , at 2

26 Some investor/State tribunals have made the distinction between the existence of $a$ minimum standard of treatment for aliens and of the minimum standard of treatment, suggesting that there mav be different standards. See in this regard the award in Alex Genin, Eastern Credit Limited, Inc. and A.S. Baltoil and the Republic of Estonia (International Centre for Settlement of Investment Disputes, In the Matter of the Arbitration between Alex Genin, Eastern Credit Limited, Inc. and A.S. Baltoil and the Republic of Estonia, Case No. ARB/99/2. Award, June 25, 2001, 367. (Members: L. Yves Fortier, Meir Heth and Albert Jan Van Den Berg). available at http://www.worldbank.org/icsid/cases/genin.pdf. [hereinafter Genin]); the award in Saluka Investments BV (the Netherlands) v. The Czech Republic. (The Matter of and Arbitration under the UNCITRAL Arbitration Rules 1976. Partial Award, Saluka Investments BV (the Netherlands) v. The Czech Republic. March 17, 2006, 295. (Members of the Tribunal: Sir Arthur Watts, L. Yves Fortier, and Peter Behrens). available at http://www.pca-cpa.org/showpage.asp?ac=print\&pag_id=1213 [hereinafter Saluka]). Ian Brownlie holds a similar view. See Ian Brownlie, PRINCIPLES OF INTERNATIONAL LAW $5^{\text {th }}$ ed. (Oxford: Oxford University Press, 1998 ) at 529.

27 This is not to say that aliens can be treated in any way by States, but that the treatment depends on the factual situation of the alien and on the application to such facts of particular rules of international law, such as humanitarian international law or the Vienna Convention on Consular Relations, which, in particular, gives aliens specific rights when detained or imprisoned in States party to the Convention. But the content of a general standard to be applied, regardless of specific factual situations, is uncertain. 
The interpretation of this provision issued by the Free Trade Commission stipulates that "Article 1105.1 prescribes the customary international law minimum standard of treatment of aliens as the minimum standard of treatment to be afforded to investments of investors of another Party.",28 Therefore, for NAFTA States, not only is there a minimum standard of treatment, but there is also the view that the standard has the status of customary international law. In this respect, it can be said that there is nothing preventing States from agreeing on whatever provisions they think suit their needs. They can assume that the minimum standard of treatment has a certain content and nature under international law. However, such assumption applies only to parties to these treaties.

Moreover, it is important to say that, though it may seem strange, the inexistence of even a general definition of the minimum standard of treatment under general international law does not prevent international arbitration tribunals from applying, when they are called upon to do so, the provisions of those bilateral and regional treaties that take such content for granted. However, these arbitration tribunals are applying bilateral treaty text only and not truly customary rules of international law as defined by Article 31 of the Statute of the International Court of Justice. This provision establishes the two requirements for the recognition of rules of customary international law, namely, uniform State practice and States' belief that it is a legal obligation, also known as opinio juris.

In other words, investor/State arbitration tribunals simply assume the existence of the custom, as ordered by the treaty, and try to define its content according to their understanding of what parties to the treaty consider to be the substance of the minimum standard of treatment of aliens. This is precisely what, for instance, the NAFTA Chapter 11 Tribunal did in Mondev International Ltd. v. United States of America. There, the Tribunal refused to assess whether there was a customary rule establishing the minimum standard of treatment of aliens; instead, it rightly took this standard as a given and sought to ascertain its content. The Moldev Tribunal pointed out:

Thus the question is not that of a failure to show opinio juris or to amass sufficient evidence demonstrating it.

28 The interpretation is available at http://www.dfait-maeci.gc.ca/tna-nae/NAFTA-Interpr-e.asp. 
The question rather is: what is the content of customary law providing for fair and equitable treatment and full protection and security in investment treaties? ? $^{29}$

Then the Tribunal moved on to define the content of the standard based on the NAFTA parties' understanding of the customary rule they considered as extant. ${ }^{30}$

But the minimum standard of treatment for aliens, whatever its content, is not only applied by international tribunals ordered by treaty law to give substance to customary rules that the parties to the treaty consider as extant, but also by other arbitration tribunals applying treaties that do not contemplate the standard explicitly. In effect, some tribunals have resorted to their particular view as to the content of the minimum standard of treatment for aliens in order to justify how they apply the respective standards of treatment used in BITs. ${ }^{31}$ To do so, they do not have to determine whether or not the standard is customary international law, but to define its substance, and they usually do so on the basis of other treaties or a few international decisions such tribunals find persuasive.

Summarizing, in the two abovementioned circumstances, arbitration tribunals invoke the

29 International Centre for Settlement of Investment Disputes (Additional Facility), Award, Mondev International Ltt. v. United States of America, October 11, 2002. Case No. ARB(AF)/99/2. 113. (Members of the Tribunal: Sir Ninian Stephen, James Crawford and Judge Stephen M. Schwebel). available at http://www.naftaclaims.com/disputes_us_mondev.htm [hereinafterMondev].

30 The Mondev Tribunal expressed:

$[1 \mathrm{t}$ is often difficult in international practice to establish at what point obligations accepted in treaties, multilateral or bilateral, come to condition the content of a rule of customary international law binding on States not party to those treaties. Yet the United States itself provides an answer to this question, in contending that, when adopting provisions for a fair and equitable treatment and full protection and security in NAFTA (as well as in other BITs), the intention was to incorporate principles of customary international law. Whether or not explanations given by a signatory government to its own legislature in the course of ratification or implementation of a treaty can constitute part of the travauxpréparatoire of the treaty for the purpose of its interpretation, they can certainly shed light on the purpose and approaches taken to the treaty, and thus can evidence opinio juris. For example the Canadian Statement on Implementation of NAFTA states that Article 1105(1) 'provides for a minimum absolute standard of treatment, based on long-standing principles of customary international law'. The numerous transmittal states of the United States of BITs containing language similar to that of NAFTA show the same general approach. For example, the transmittal statement with respect to the United States-Ecuador BIT of 1993 states that the guarantee of fair and equitable treatment 'sets out a minimum standard of treatment based on customary international law'. It is to be noted that these official statements repeatedly refer not to 'the' but to 'a' minimum standard of treatment....

$[\mathrm{M}]$ exico ... did not have a practice prior to NAFTA of concluding BITs, but it expressly associated itself with the Canadian Statement on Implementation.

Id. $111-2$. (footnotes omitted).

31 Arbitration tribunals doing so are applying their particular viens regarding the minimum standard of treatment of aliens because neither the International Court of Justice nor the ILC has defined the content of the standard. For instance, the ICSID Tribunal in Genin did so, when it stated:

Article II(3) of the BIT requires the signatory governments to treat foreign investment in a 'fair and equitable' way. Under international law, this requirement is generally understood to 'provide a basic and general standard which is detached from the host State's domestic law.' While the exact content of this standard is not clear, the Tribunal understands it to require an 'international minimum standard' that is separate from domestic law, but that is, indeed, a minimum standard. Acts that would violate this minimum standard would include acts showing a willful neglect of duty, an insufficiency of action falling far below international standards, or even subjective bad faith ...

Genin, supra note 26, 367. 
minimum standard of treatment of aliens as a customary international law not to apply this law, since its content is uncertain, as was illustrated, but to give it the substance such tribunals regard as necessary to dispose of the case at hand under a bilateral or regional treaty. It is a very rational decision for these tribunals, since they have to apply bilateral treaty text only. However, the ICJ is in a completely different position from investor/State arbitration tribunals, and it is prevented from approaching the issue of the minimum standard of treatment of aliens as these tribunals do. As well, the ICJ is in a more privileged and complex position than any investor/State arbitration tribunal, because while the latter knows that its award may have certain persuasive value-but no more than that-for other tribunals, the ICJ is well aware of the fact that it has the power to shape the evolution of international law.

In this sense, the approaches of the ILC and of some arbitration tribunals to the minimum standard of treatment of aliens are not useful for the ICJ when deciding the Diallo case. That of the former does not provide any orientation at all; nor does the latter, since the ICJ in the said dispute is not under the duty to apply treaty law contemplating the minimum standard of treatment or any other, because there is no such treaty between Guinea and the Democratic Republic of Congo. Therefore, the ICJ has to determine the rule of international law under which it can assess whether Mr. Diallo's shareholder rights, and those of Guinea, have been violated. $^{33}$

32 For instance, as Boisson de Chazournes \& Sarah Heathcote point out:

ICJ judgments by themselves can make significant contributions to the development of customary international law, by simply stating that determined rule has become an international custom. That was the case of the Law of the Sea Tribunal's decision in M/V Saiga in which the Tribunal based the customary law status of the state of necessity on the ICJ's judgment in Gabcikovo-Nagymaros in which it declared such principle to have this character, despite the fact that controversy surrounded this recognition before the ICJ ruling. Laurence Boisson de Chazournes and Sarah Heathcote, The Role of the New International Adjudicator in David J. Bederman and Lucy Reed, eds., PROCEEDINGS OF THE 95TH ANNUAL MEETING OF THE AMERICAN SOCIETY OF INTERNATIONAL LAW (Washington: American Society of International Law, 2001) 129 133. The European Court of First Instance did the same and specifically stated in Opel Austria GmbH v. Council of the European Union (Case T - 115/94) that " $T$ T] he principle of good faith ... is a rule of customary international law, whose existence has been recognized by the International Court of Justice $\ldots$ and it is therefore binding on the Community." See in this regard also Rosalyn Higgins, The ICJ, the ECJ, and the Integrity of International Law 52 I.C.L.Q. 18 9 (2003).

33 It is important to mention that the Court is under no obligation to recognize the categorization of the minimum standard of treatment of aliens as a customary rule of international law on the sole grounds that some States have made such categorization for the purpose of their bilateral relations regarding the promotion of their investments. In effect, the ICJ has declared that, even if parties to disputes before the Court agree that there is certain rule of customary international law applicable to their case, the Court is not bound to accept such recognition and has to inquire for itself whether the rule effectively exists.

The Court held in its judgment Nicaragua that

[T] he mere fact that States declare their recognition of certain rules [of customary international law] is not sufficient for the Court to consider these as being part of customary international law, and as applicable as such to those States....

Nicaragua, supra note 5,183.

In sum, the fact that some States within or outside Court's judicial proceedings assume that a certain rule of international law has acquired the status of customary does not bind the Court. In consequence, the fact that some BITs consecrate the minimum standard of treatment of aliens as a customary international rule does not relieve the Court of its duty to carry out an inquiry into whether such rule does in fact have the said status. 
If the content of the minimum standard of treatment is in itself so elusive, an alternative apparently at the disposal of the ICJ to rule on the claims of violation of Mr. Diallo's right as shareholder would be to associate the minimum standard of treatment of aliens - in this case a foreign investor-with the fair and equitable treatment standard, on the basis of its declaration as customary international law.

\section{THE STANDARD OF FAIR AND EQUITABLE TREATMENT AS A CUSTOMARY INTERNATIONAL LAW}

In relation to the Diallo case, one could say that the ICJ has at its disposal at least two ways to resolve the problem of defining the content and nature of the minimum standard of treatment of Mr. Diallo. The first is to ascertain such content and nature independently of any standard set forth in BITs. However, given the significant difficulties in ascertaining the status and content of the standard, as illustrated by the position the ILC has taken regarding it, the ICJ could instead draw on the widespread inclusion in BITs of the fair and equitable treatment standard $^{34}$ to give to it not only the status of customary international law but also to equate it in this case with the minimum standard of treatment of aliens, by virtue of the fact that the affected alien is a foreign investor. Here is where Schwebel's suggestion $^{35}$ and the statements made by the Moldev Tribunal could become relevant. The Tribunal held:

[T] he vast number of bilateral and regional investment treaties (more than 2000) almost uniformly provide for a fair and equitable treatment of foreign investments, and largely provide for full security and protection of investments. Investment treaties run between North and South, and East and West, and between States in these spheres inter se. On a remarkably widespread basis, States have repeatedly obliged themselves to accord foreign investment such treatment. In the Tribunal's view, such a body of concordant practice

34 For a detailed evaluation of this standard see Stephen Vasciannie, The Fair and Equitable Treatment Standard in International Investment Law and Practice in 70 THE BRITISH YEARBOOK OF INTERNATIONAL LAW (Oxford: Clarendon Press, 2000) 99.

35 Andreas Lowenfeld makes a similar point, but he acknowledges that it does not satisfy the requirements of international law for the recognition of customary international rules and says that "perhaps the traditional definition of customary law is wrong, or at least in this area, incomplete." Andreas Lowenfeld, Investment Agreements and International Law 42 COLUMBIA JOURNAL OF TRANSNATIONALLAW 123130 (2003). Regardless of the general extra-legal plausibility of this argument, the ICJ is bound to apply the criteria set forth in Article 31 of the Statute as a matter of law; therefore, for the ICJ this provision is neither wrong nor incomplete. 
will necessarily have influenced the content of rules governing the treatment of foreign investment in current international law. ...

The conventional wisdom regarding the state of the ICJ jurisprudence offers some support for the belief that the ICJ could make a similar statement, since it is based on the assumption that the ICJ has relaxed the requirements for the recognition of rules of international law. An illustration of this conventional belief follows.

\section{B. THE FLEXIBLE}

\section{APPROACH TO THE DECLARATION OF RULES OF CUSTOMARY INTERNATIONAL LAW}

The conventional wisdom regarding the ICJ's prevailing approach to the recognition of rules of customary international law could provide grounds for expecting from the Diallo judgment on the merits a potential declaration of the minimum standard of treatment of aliens as a customary international law defined by the fair and equitable treatment standard. Yasuaki illustrates this conventional wisdom, according to which the ICJ would have loosened the requirements for the recognition of rules of customary international law, thus:

It is well known that the ICJ has used the notion of customary international law in a highly flexible manner. The ICJ has blurred the distinction between state practice and opinio juris in demonstrating norms of customary international law. It has also become more inclined to rely on United Nations General Assembly declarations and resolutions as well as multilateral treaties to demonstrate the customary rules and principles of general international law. Further, the ICJ has relaxed the time requirement in the formation of general customary law.... Such deviations are the un avoidable and understandable methods through which the ICJ identifies binding norms within the framework of Article 38 of the ICJ Statute. Because there is no treaty binding all states in international society, the ICJ is compelled to apply either 
rules of "customary" law or "general principles of law recognized by civilized nations", when it is required to apply norms with universal validity. Because the latter has many disadvantages, the ICJ has chosen the former. As a consequence, the ICJ is compelled to demonstrate norms of universal validity in terms of customary law even in situations where it is difficult to do so according to the traditional, "rigid" doctrine of customary law.

The flexible approach developed by the ICJ regarding the requirements for the declaration of rules of customary international law was adopted in its judgment in Nicaragua. The main features of this flexible jurisprudence are three. First, complete uniformity of State practice is not necessary for a customary rule of international law to emerge. In fact, States' behaviour contrary to the practice would constitute a violation of the rule rather than preventing it from crystallizing as customary. ${ }^{38}$ The second fundamental feature of this flexible trend is the loosening of the requirements for inference of the existence of opinio juris. This second requirement may not only be inferred from States' beliefs that they are complying with a mandatory precept, but also from Declarations of the UN General Assembly. ${ }^{39}$ The third significant characteristic of this flexible approach-though not entirely relevant to the Diallo case-is the recognition that customary international law does not lose such nature when it is embodied in multilateral treaties. ${ }^{40}$

The Nicaragua judgment loosened the requirements to declare the existence of customary international law. Schachter considered that Nicaragua inversed the process of

37 Onuma Yasuaki, Is the International Court of Justice an Emperor Without Clothes? 8 INTERNATIONAL LEGAL THEORY 319 - 20 (2002).

38 The ICJ held:

[T] he Court does not consider that, for a rule to be established as customary, the corresponding practice must be in absolute rigorous conformity with the rule. In order to deduce the existence of customary rules, the Court deems it sufficient that the conduct of States should, in general, be consistent with a given rule, and that instances of State conduct inconsistent with a given rule should generally have been treated as breaches of that rule, not as indications of the recognition of a new rule.... Nicaragua, supra note 5, 186.

39 The ICJ pointed out:

[T] he Court has however to be satisfied that there exists in customary international law an opinio juris as to the binding character of such abstention. This opinio juris may, though with all due caution, be deduced from, inter alia, the attitude of the Parties and the attitude of States towards certain General Assembly resolutions, and particularly resolution 2625 (XXV) entitled "Declaration on Principles of International Law concerning Friendly Relations and Co-operation among States in accordance with the Charter of the United Nations". The effect of consent to the text of such resolutions cannot be understood as merely that of a "reiteration or elucidation" of the treaty commitment undertaken in the Charter. On the contrary, it may be understood as an acceptance of the validity of the rule or set of rules declared by the resolution by themselves....

Id. 188.

40 Seeid. 174 
creation. Under the strict approach, State practice came first, and opinio juris followed it. ${ }^{41}$ After the aforementioned decision, opinio juris appears first as a declaration embodied in a UN General Assembly Resolution; then State practice will confirm the customary character of the given declaration. ${ }^{42}$

However, the flexible approach of the Court towards customary international law, as articulated in Nicaragua, was attenuated ten years later in the Court's advisory opinion in Legality of the Threat or Use of Nuclear Weapons. There, the UN General Assembly asked the Court to answer the question of whether the threat or use of nuclear weapons was in any circumstance permitted under international law. ${ }^{43}$ In this Advisory Opinion, the Court did not take the same path followed in Nicaragua and refined the conditions under which General Assembly resolutions may reach customary international law status.

The Court notes that General Assembly resolutions, even if they are not binding, may sometimes have normative value. They can, in certain circumstances, provide evidence important for establishing the existence of a rule or the emergence of an opinio juris. To establish whether this is true of a given General Assembly resolution, it is necessary to look at it $\mathrm{s}$ content and the conditions of its adoption; it is also necessary to see whether an opinio juris exists as to its normative character. Or a series of resolutions may show the gradual evolution of the opinio juris required for the establishment of a new rule. ${ }^{44}$

41 Assessing Nicaragua, Theodore Meron said:

$[\mathrm{W}]$ here a treaty concerns a particular area of law, however, even if it does not bind the parties to the dispute in question, the ICJ has tended to treat the texts of the treaty as a distillation of the customary rule. Eschewing examination of primary materials establishing stated practice and opiniojuris....

Theodor Meron, Revival of Customary Humanitarian Law 99 AMERICAN JOURNAL OF INTERNATIONAL LAW 817819 (2005).

42 Oscar Schachter, New Custom: Power, Opinio Juris and Contrary Practice in Jerzy Makarczyk, ed., THEORY OF INTERNATIONAL LAW AT THE THRESHOLD OF THE $21^{\text {ST }}$ CENTURY: ESSAYS IN HONOUR OF KRZYSZTOF SKUBIESZEWSKI (The Hague: Kluwer Law International, 1996) 531 532. See also W. Michael Reisman, The Cult of Custom in the Late 20 Century 17 Cal. W. Int'l L.J.133 (1987).

43 UN General Assembly Resolution 49/75 K, 15 December 1994. A strict application of Nicaragua would have eventually led to the declaration that the use of nuclear weapons was condemned by customary international law. In effect, on November 24, 1961, the General Assembly adopted Resolution 1653(XVI) declaring the use of nuclear weapons "a direct violation of the Charter of the United Nations." International Court of Justice. Legality of the Threat or Use of Nuclear Weapons, Advisory Opinion of 8 July 1996. [1996] I.C.J. Rep. 226 71. [hereinafter Nuclear Weapons]. Moreover, since 1961, according to the Court, the General Assembly had enacted resolutions each year invoking Resolution 1653 and requesting member States to conclude a treaty banning the use of nuclear weapons. Such resolutions, said the Court, had been adopted by large majorities. See id. 73 . 
On this occasion, negative votes against the UN Resolutions and State practice contrary to the rule were seen as acts preventing the rule from crystallizing as customary international law. ${ }^{45}$ It is important to state that, in its advisory opinion in Legality of the Threat or Use of Nuclear Weapons, the Court attenuated but did not reverse the position it took in Nicaragua regarding customary international law, so the flexible trend persists.

Thus, high expectations as to the recognition of the myriad of BITs as a potential expression of the emergence of the fair and equitable treatment standard as a customary rule of international law, as Schwebel and others suggest, would certainly be well placed in the ICJ's flexible approach regarding customary international law. In effect, complete uniformity in the formulation of the standard of fair and equitable treatment in BITs would not be required, and its inclusion in thousands of BITs could be seen as satisfying the lowered threshold of opinio juris established in Nicaragua. Had the ICJ declared the fair and equitable treatment standard a customary rule of international law, it would not be too difficult to equate the standard with the minimum standard of treatment of aliens under international law in the Diallo case, in which a foreign investor is involved.

In sum, three factors contribute to placing high hopes on the Diallo judgment on the merits. First, the minimum standard of treatment is not as such defined in general public international law. Second, such uncertainty could eventually offer the ICJ the possibility to resort to the fair and equitable treatment standard in this particular case, by declaring it a customary rule of international law. Third, this declaration would be at least possible in principle, since the ICJ has a flexible approach to the recognition of such customary rules in which it has lowered the threshold of opinio juris required for this recognition.

\section{REASONS CONSPIRING AGAINST GREAT FOREIGN INVESTORS' EXPECTATIONS IN THE ICJ'S JUDGMENT ON THE MERITS IN THE DIALLO CASE}

Although the set of factors supporting significant expectations of the ICJ judgment on the merits in the Diallo dispute may have merit, this author is

45 Seeid. $71 \& 73$ 
of the view that other important circumstances point in a completely opposite direction and that it is unlikely that the ICJ will equate the minimum standard of treatment of aliens applicable to Mr. Diallo, as foreign investor, with the standard of fair and equitable treatment on the basis of its declaration as customary international law.

These circumstances are also three: first, in tandem with the flexible approach to the recognition of customary international rules, the ICJ has a strict approach, precisely designed and applied for such declaration in relation to bilateral or multilateral international treaties, as to the declaration of customary international law. Second, this approach, although it had been dormant for two decades, was recently revived by the Court precisely in its decision on preliminary objections in the Diallo case. Third, some important States are moving away from according foreign investors higher levels of protection and are seeking new ways to reduce such levels. The ICJ obviously is or would be aware of this reality and would take it into consideration, since declaring the standard of fair and equitable treatment as a customary rule of international law would go against this recent attitude evinced by States.

\section{A. THE UNLIKELY DECLARATION OF THE PRINCIPLE OF FAIR AND EQUITABLE TREATMENT STANDARD AS A CUSTOMARY INTERNATIONAL LAW}

The second trend of the ICJ jurisprudence concerning customary international law is marked by the requirement of high thresholds for State practice to acquire the status of rules of this nature. The underlying justification of this strict approach is that declarations of rules as customary international law imply that all States have to comply with the relevant rules, regardless of whether or not they have participated in their development and regardless of the impact of such rules on their interests. Therefore, it is not surprising that, given such a reality, the Court adopted a strict approach towards the recognition of rules of customary international law embodied in international treaties negotiated by a limited number of States. The ICJ set the basis of this strict approach in its judgment in the North Sea Continental Shelf Cases cases. ${ }^{46}$

46 International Court of Justice. North Sea Continental Shelf Cases (Federal Republic of Germany/Denmark; Federal Republic of Germany /Netherlands), Judgment of 20 February 1969. [1969] I.C.J. Rep. 3. [hereinafter North Sea Continental Shelf]. 
This dispute arose out of the Netherlands' and Denmark's contention that the principle of equidistance in the delimitation of continental shelves, consecrated in Article 6 of the Geneva Convention and whose application they were seeking in their dispute with the Federal Republic of Germany, had later acquired the status of customary international law due to States' practice and the work of the ILC.

The Court declared that the process of a treaty becoming an international custom was possible ${ }^{48}$ but stated that "this result is not lightly to be regarded as having been attained." ${ }^{49}$ Then the Court proceeded to establish strict requirements for the transformation of treaty provisions binding on a few States into rules of international customary law binding on all. First, the treaty provisions must not be one with regard to which reservations by parties to the treaty are permitted. ${ }^{50}$ Second, the international convention must have been the subject of widespread ratification by States most interested in or affected by the given provision. ${ }^{51}$ Third, the transformation of treaty law into customary international law usually requires the passage of a considerable amount of time. However, such transformation can take place in a short span of time, but in order for this to happen, the practice must be virtually uniform. ${ }^{52}$ Finally, the ICJ set a high threshold for the opinio juris and determined that it had to be demonstrated that States adopting the practice regarded it as mandatory and not because they thought it convenient. The Court held:

The essential point in this connection - and it seems necessary to stress it-is that even if these instances of action by non-parties to the Convention were much more numerous than they in fact are, they would not, even in the aggregate, suffice in themselves to constitute the opinio juris;- - for, in order to achieve this result, two conditions must be fulfilled. Not only must the acts concerned amount to a

47 Id. 61. Although Denmark and the Netherlands were parties to the Convention, the Federal Republic of Germany was not, which led the former to rise the argument of the transformation of Article 6 as a rule of customary international law binding on the latter. Seeid. 26.

48 Seeid. 71.

$49 \quad I d$.

50 Seeid. 72

51 See id. 73. In this particular case, the ICJ considered that the fact that 50 States had ratified the Convention was not indication of widespread support for the provision up to the point of making the Convention a rule of customary international law. See id.

52 Seeid. 74 
settled practice, but they must also be such, or be carried out in such a way, as to be evidence of a belief that this practice is rendered obligatory by the existence of a rule of law requiring it. The need for such a belief, i.e., the existence of a subjective element, is implicit in the very notion of the opinio juris sive necessitates. The States concerned must therefore feel that they are conforming to what amounts to a legal obligation. The frequency or even habitual character of the acts is not in itself enough. There are many international acts, e.g., in the field of ceremonial an protocol, which are performed almost invariably, but which are motivated only by considerations of courtesy, convenience or tradition, and not by any sense of legal duty.
It is also worth mentioning that, chronologically, the ICJ first adopted the strict approach towards declaration of rules of customary international law, ${ }^{54}$ and then the flexible one, which led many authors to refer to the traditional and modern approaches of the Court to customary international law. Current developments in the jurisprudence of the Court have made this distinction meaningless, since the strict approach has been recently applied by the Court and precisely in its decision in the Diallo case on preliminary objections.

\section{B. THE RECENT APPLICATION OF THE STRICT TREND REGARDING CUSTOMARY INTERNATIONAL LAW}

The belief that the flexible approach is the dominant one regarding customary international law has been based on the fact that the strict

53 Id. 77. The ICJ concluded in this case that the equidistance principle was used to demark the continental shelf for reasons other than the States' belief of its being the application of a mandatory rule. (See id. 78). For all these reasons, the ICJ determined that Article 6 of the Geneva Convention had not attained the status of international customary law. See id. 81. For a detailed analysis of this judgment regarding customary international law, see Peter Haggenmacher, "La Doctrine de Deux Éléments du Droit Coutumier Dans la Pratique de la Cour Internationale” LXXXX R.G.D.I.P. 1 (1986).

The strict approach was followed few years later by a cautious view regarding the identification not of rules, of but of trends, in the evolution of customary international law in certain domains. This cautious approach was embodied in the Court's judgment in the Case Concerning the Continental Shelf (Tunisia/Libyan Jamabiriya). Although the ICJ was asked to rule on the basis of emerging trends regarding the law of the Sea, the Court refrained from taking this path. See International Court of Justice. Case Concerning the Continental Shelf (Tunisia/Libyan Jamabiriya), Judgment of 24 February 1982. [1982] I.C.J. Rep. 18 24. The Court sent the question back to the parties and asked them to themselves identify those trends they considered the Court should apply instead of making the Court itself make such selection. The parties, not the Court, ended up making such identification. See id. 46.

54 See Anthea Elizabeth Roberts, Traditional and Modern Approaches to Customary International Law: A Reconciliation 95 AMERICAN JOURNAL OF INTERNATIONAL LAW 757 (2001). 
approach came first and had not been recently applied by the Court. The fact that this line of jurisprudence has always been available is evidenced by its implicit application in the decision on preliminary objections in the Diallo case.

As was mentioned, in the case before the ICJ, Guinea sought to exercise its diplomatic protection on behalf of Mr. Diallo as an individual and as $\operatorname{associé}^{55}$ of Africom and Africontainers-two Congolese companies_and, specifically, his rights to oversee, control and manage the companies. Guinea also exercised its right to diplomatic protection, by substitution, of these companies in order to recover the debts owed to them, ${ }^{56}$ despite the fact that the ICJ had declared in its judgment in Barcelona Traction that only the State of incorporation of legal persons could seek their diplomatic protection. ${ }^{57}$

To support this claim, Guinea argued that multiple BITs and international arbitration awards had recognized that shareholders could seek reparation for damages caused by host States to their companies.
The Court did not accept this argument, tacitly applying the strict jurisprudence by saying:

The fact invoked by Guinea that various international agreements, such as agreements for the promotion and protection of foreign investments and the Washington Convention, have established special legal regimes governing investment protection, or that provisions in this regard are commonly included in contracts entered into directly between States and foreign investors, is not sufficient to show that there has been a change in customary rules of diplomatic protection; it could equally show the contrary. The arbitrations relied on by Guinea are also special cases, whether based on specific international agreements between two or more States, including the one responsible for the allegedly unlawful acts regarding the companies concerned ... or based on agreements concluded directly between a company

\footnotetext{
The term associé is the one used by the Court in its decision. See Diallo, supra note 1, 25

Seeid. $27-29$.

See Barcelona Traction, supra note 23, 70.
} 
and the State allegedly responsible for the prejudice to it ... ${ }^{58}$

As can be seen, in its Decision on Preliminary Objections in the Diallo dispute, in which it was asked to consider multiple BITs as evidence of changes in customary international law, the Court did not apply the flexible approach of Nicaragua; on the contrary, it applied its strict jurisprudence for the recognition of rules of customary international law, which means that both approaches persist today in this realm. ${ }^{59}$

The ICJ's decision on preliminary objections in Diallo may be seen as going against hopes that the proliferation of BITs could lead to a declaration that the standard of fair and equitable treatment of foreign investors provided therein constituted customary international law. The flexible approach was not applied by the Court precisely in the field-protection of foreign investors-in which Schwebel and others could have eventually counted on to see materialized their hope of seeing the fair and equitable treatment standard elevated to the status of rule of customary international law.

There is virtually no need to go into the elements of the strict approach to confirm that the fair and equitable treatment standard has not reached such status under this threshold. There are States that do not have BITs, or even if they have them, have only a few. But even if they have many, they do not think they are obliged to accord the standard to investors of States with which no BIT is in place. In sum, leaving aside the fact that there is a uniform practice regarding the recognition of the standard, it lacks opinio juris. States bind themselves because they think it is convenient for their interest and for their investors in the particular treaty in question and in relation with the particular counterpart, but they do not do so because they feel they are compelled to grant such standard of treatment. ${ }^{60}$ The

58 Diallo, supra note 2, 90. On this basis, the Court upheld the preliminary objection invoked by the Democratic Republic of Congo and declared that Guinea did not have standing to exercise its diplomatic protection on behalf of the companies of which Mr. Diallo was an associé. See id. 89.

59 The ICJ did not quote its previous judgment in North Sea Continental Shelf Cases as a basis to reject Guinea's claim. Such absence does not prevent me from arguing that the ICJ revived the strict approach towards the recognition of customary rules of international law, since the conclusion of the ICJ shows that it did not apply the flexible approach of Nicaragua.

60 It is not surprising that this was the position of Canada, Mexico and United States in the Mondev case. The Tribunal held:

"[A]ll three NAFTA Parties challenged holding of the Tribunal in Polpe \& Talbot which find that the content of contemporary international law reflects the concordant provisions of many hundreds of bilateral investment treaties. In particular, attention was drawn to what those three States saw as a failure of the Pope \& Talbot Tribunal to consider a necessary element of the establishment of a rule of customary international law namely opinio juris. These States appear to question whether the parties to the very large numbers of bilateral investment treaties have acted out of a sense of legal obligation when they include provisions in those treaties such as that for' fair and equitable' treatment of foreign investment."

Moldev, supranote 29, 110. 
subjective element of customary international law is by no means present regarding the fair and equitable treatment standard.

In its judgment on the merits with regard to the proliferation of treaties consecrating the fair and equitable treatment standard, the Court could also reiterate what it said in the Diallo decision on preliminary objections as to the proliferation of BITs allowing investors to seek protection for damages caused to their companies: that the inclusion of the fair and equitable treatment standard in BITs proves precisely that it has not reached the status of customary international law.

But the unlikelihood of a declaration of the fair and equitable treatment standard as a customary rule of international law is not only associated with an application of the requirements of the strict jurisprudence adopted by the ICJ regarding economic subject-matters, but also with the fact that such declaration would not fit well with the position States are adopting regarding the level of protection accorded to foreign investors.

\section{DIALLO IN THE CONTEXT OF STATES' RECENT ATTITUDE AIMED AT NARROWING THE LEVEL OF PROTECTION ACCORDED TO FOREIGN INVESTORS}

It does not come as a surprise that the ILC decided not to deal with the issue of the minimum standard of treatment of aliens, since States themselves have been unable to arrive at a common ground. ${ }^{62}$ Moreover, as Orrego Vicuna highlighted before the $99^{\text {th }}$ Annual Meeting of the American Society of International Law, important States that in the past were promoting high levels of protection for foreign investors are now seeking to commit themselves to lower degrees, due to the change in their status from capital exporters to capital importers of foreign investment, as evidenced for instance in the interpretation of NAFTA Article 1105, which undeniably sought this objective. ${ }^{63}$

61 There is no contradiction in the co-existence of the flexible and strict approaches to customary international law in the ICJ, since both seem to be applied to different areas of international law. The flexible approach is most used with regard to humanitarian international law, while the strict approach has been to date applied by the Court to issues unrelated to this field, among them subject-matters of economic nature, including continental shelves and foreign investment.

62 As evidenced by the failure of the negotiations of the Multilateral Investment Agreement. See in this regard, Philippe Sands, LAWLESS WORLD (New York: Viking, 2005) 138 -9.

63 Francisco Orrego Vicuna, Foreign Investment Law: How Customary is Custom? in Laurence R. Helfer \& Rae Lindsay, eds., NEW ORDER OR A WORLD IN DISORDER? TESTING THE LIMITS OF INTERNATIONAL LAW. PROCEEDINGS OF THE $99^{T H}$ ANNUAL MEETING OF THE AMERICAN SOCIETY OF INTERNATIONAL LAW (Washington: American Society of International Law, 2005)9798-9. 
In other words, the trend in some important States is towards lower, not higher levels of protection of foreign investors. Declaring the fair and equitable treatment standard as a customary rule of international law would go against this trend, and since the ICJ is expected to be well aware of and unlikely to ignore this contemporary reality, it is even more unrealistic to expect that the Court will make such a declaration. ${ }^{64}$

Certainly, given today's politics in the field of international protection of foreign investment, it is unrealistic to consecrate the fair and equitable treatment standard as a rule of customary international law. Although BITs certainly proliferate, they are negotiated in detail in terms of content; States carefully choose which counterparts they will celebrate them with; and the pattern for some important capital exporters in some BITs is towards narrow interpretations of the level of protection provided.
Finally, it is important to say that if there is an international arbitration award that would provide a result in the merits of the Diallo case that would fit well with the realities in the field of States' contemporary policy as to the level of protection of foreign investors, it is the award in Saluka Investments BV(the Netherlands) v. The Czech Republic. In Saluka, the Tribunal stated that the minimum standard of treatment of aliens under international law offers a level of protection lower than the fair and equitable treatment standard provided for in BITs. The Tribunal held: [I] $\mathrm{t}$ should be kept in mind that the customary minimum standard is in any case binding upon a State and provides a minimum guarantee to foreign investors, even where

64 A former President of the ICJ, Judge Mohammed Bedjaoui, while acting in that capacity, stated clearly that the ICJ keeps a close eye on the external realities. When presenting the Court's annual report to the UN General Assembly, he said:

[T] he Court, by the nature of the law it applies, by the role it fulfils and by its composition, is better able than any other judicial institution to withstand blind applications of the law. While being sufficiently precise to offer those who come before it all the legal security to which they legitimately aspire, international law remains at the same time and in essence a flexible and open law....

The Court takes its decisions on the basis of law, following a most minute and meticulous examination of each case, without failing to take into account of the meta-juridical factors, the expectations of the parties and the imperative requirements of peace and justice...

Judge Mohammed Bedjaoui, as quoted by Elihu Lauterpacht. Elihud Lauterpacht, The Judicial and the Meta-Juridical in International Law in Jerzy Makarczyk, ed., THEORY OF INTERNATIONAL LAW AT THE THRESHOLD OF THE $21^{\text {sT }}$ CENTURY: ESSAYS IN HONOUR OF KRZYSZTOF SKUBIESZEWSKI (The Hague: Kluwer Law International, 1996) 215216.

Likewise, Sir Robert Jennings also acting as President of thee ICJ expressed a similar view in its report to the U.N. General Assembly. He said:

[A] court must indeed apply legal rules and be seen clearly to be doing so, for otherwise it forfeits such authority as it has, for its authority arises not from the pronouncements of judges but from pronouncements of what the law is. Nevertheless, a good and useful court will not be ignorant of the political issues involved or of the political consequences of the decision it takes.

Sir Robert Yewdall Jennings, Report of the International Court of Justice UN Doc. A/46/PV.44. (1991), reprinted in 86 AMERICAN JOURNAL OF INTERNATIONAL LAW 249252 (1992). 
the States follows a policy that is in principle opposed to foreign investment; in that context, the minimum standard of 'fair and equitable treatment' may in fact provide no more than 'minimal' protection. Consequently, in order to violate that standard, States' conduct may have to display a relatively higher degree of inappropriateness.

Bilateral investment treaties, however, are designed to promote foreign direct investment as between the Contracting Parties, in this context, investors' protection by the 'fair and equitable treatment' standard is meant to guarantee providing a positive incentive for foreign investors. Consequently, in order to violate the standard, it may be sufficient that States' conduct displays a relatively lower degree of inappropriatness. ${ }^{65}$

As can be seen, for the Saluka Tribunal the level of protection granted to foreign investors by the minimum standard of treatment of aliens is not the one offered by the fair and equitable treatment standard, at least as understood in those BITs that do not link it to the minimum standard of treatment. ${ }^{66}$

One could speculate that this result could eventually be the one that would allow the Court to offer a level of standard of protection of aliens under the institution of diplomatic protection, where BITs are not present, and which would fit well with the contemporary realities in some States who seek to accord foreign investors lower degrees of protection even under BITs.

Finally, the fact that the ICJ may not resort to the fair and equitable treatment standard when deciding Guinea's claim that Mr. Diallo did not receive treatment in accordance with a "minimum standard of civilization" from the DRC does not mean that the ICJ will not rule on this claim. In fact, one of the important contributions the judgment on the merits of this case may provide is what the content of this standard is-whatever the label the Court will assign it. In this sense, it will be important to see whether the ICJ embraces the bottom line or uses a standard similar to that set by the Mexico-US General Claims

65 Saluka, supra note 26, 292-3.

66 This was the case in Saluka with the Agreement on Encouragement and Reciprocal Protection of Investments Between the Kingdom of The Netherlands and the Czech and Slovak Federal Republic. See id. 294-5. 
Commission in the Neer case, which has received considerable attention in investor/State arbitration. According to this award:

The treatment of an alien, in order to constitute an international delinquency, should amount to an outrage, to bad faith, to willful neglect of duty, or to an insufficiency of governmental action so far short of International standards that every reasonable and impartial man would readily recognize its insufficiency.

\section{CONCLUSION}

This paper has highlighted the fact that critical issues for States and foreign investors are at stake in the Diallo case before the International Court of Justice, in which Guinea is exercising its right to diplomatic protection on behalf of its national as assoccie in two Congolese companies, and it is claiming that the DRC has violated the "the principle that aliens should be treated in accordance with a 'minimum standard of civilization."'

Three factors contribute to foreign investors' positive expectations in the final judgment in the Diallo case.
First, the content and nature of the minimum standard of treatment of aliens is not as such defined in public international law. Second, such lack of definition could offer the ICJ the eventual possibility of resorting to the fair and equitable treatment standard to rule on Guinea's abovementioned claim, by declaring the standard as a customary rule of international law and by equating it with the minimum standard of treatment. Third, such declaration is at least possible in principle, since the ICJ has a flexible approach in which it has loosened the threshold of opinio juris required for this recognition.

Although the set of factors supporting significant expectations in the ICJ judgment on the merits in the Diallo dispute are indeed present, this paper has shown that other important circumstances conspire against such expectations and that it would not seem probable that, to decide the foregoing claim, the ICJ would declare the fair and equitable treatment standard as customary international law to give content to the minimum standard of treatment of aliens in this particular case.

In sum, first, the Diallo case could offer the ICJ the opportunity to give

67 Neer(U.S.)v. United Mexican States, 4 R.I.A.A. 60 (Mexico-U.S. General Claims Commission) (1926). 
the long-awaited clarification of the content or a content of the minimum standard of treatment of aliens, at least with regard to foreign investors, a task the ILC has been reluctant to accomplish for good reasons. And second, it is unlikely that, as a result of this case, the fair and equitable treatment standard will end up receiving the official status of customary international law.

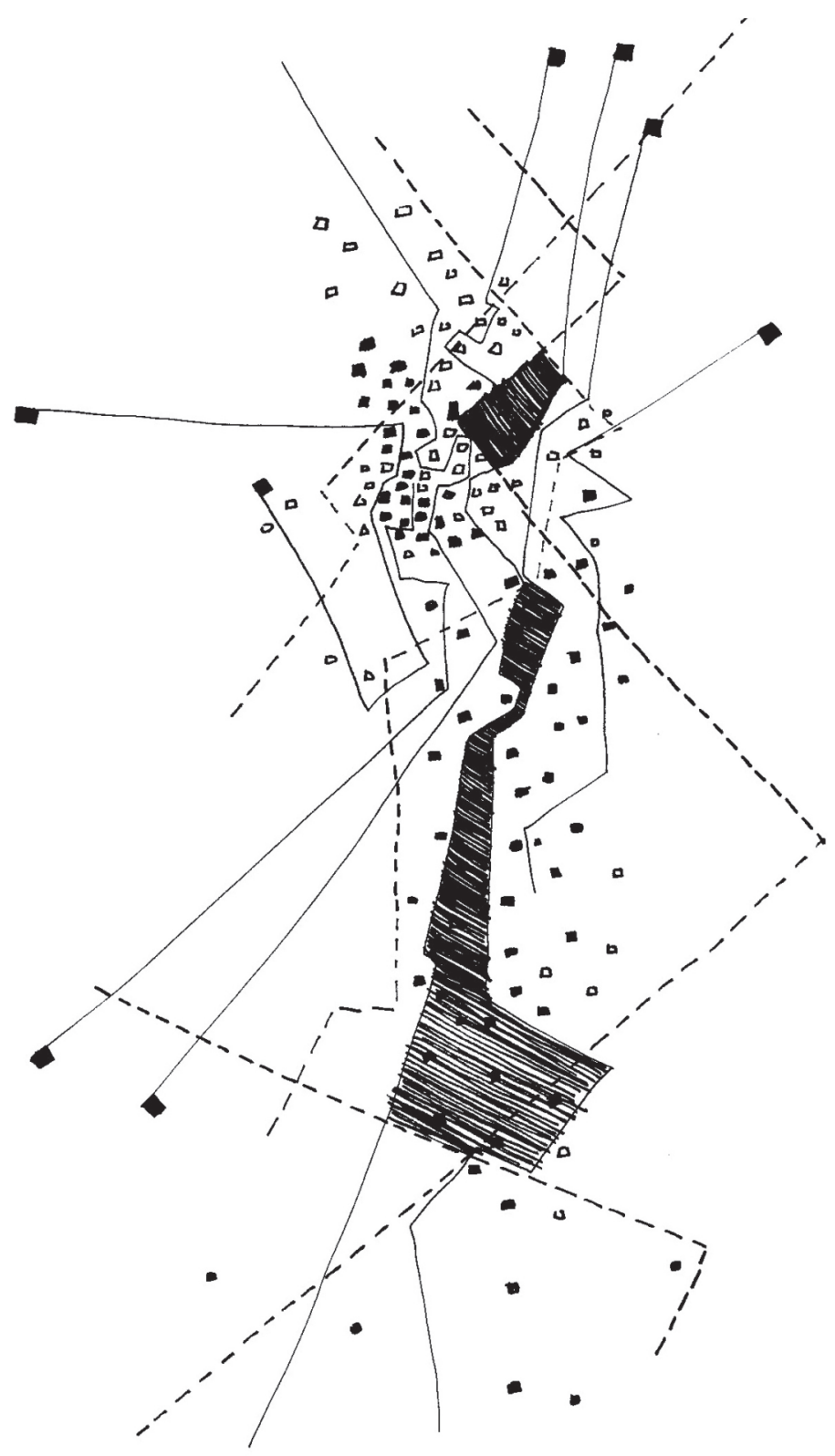




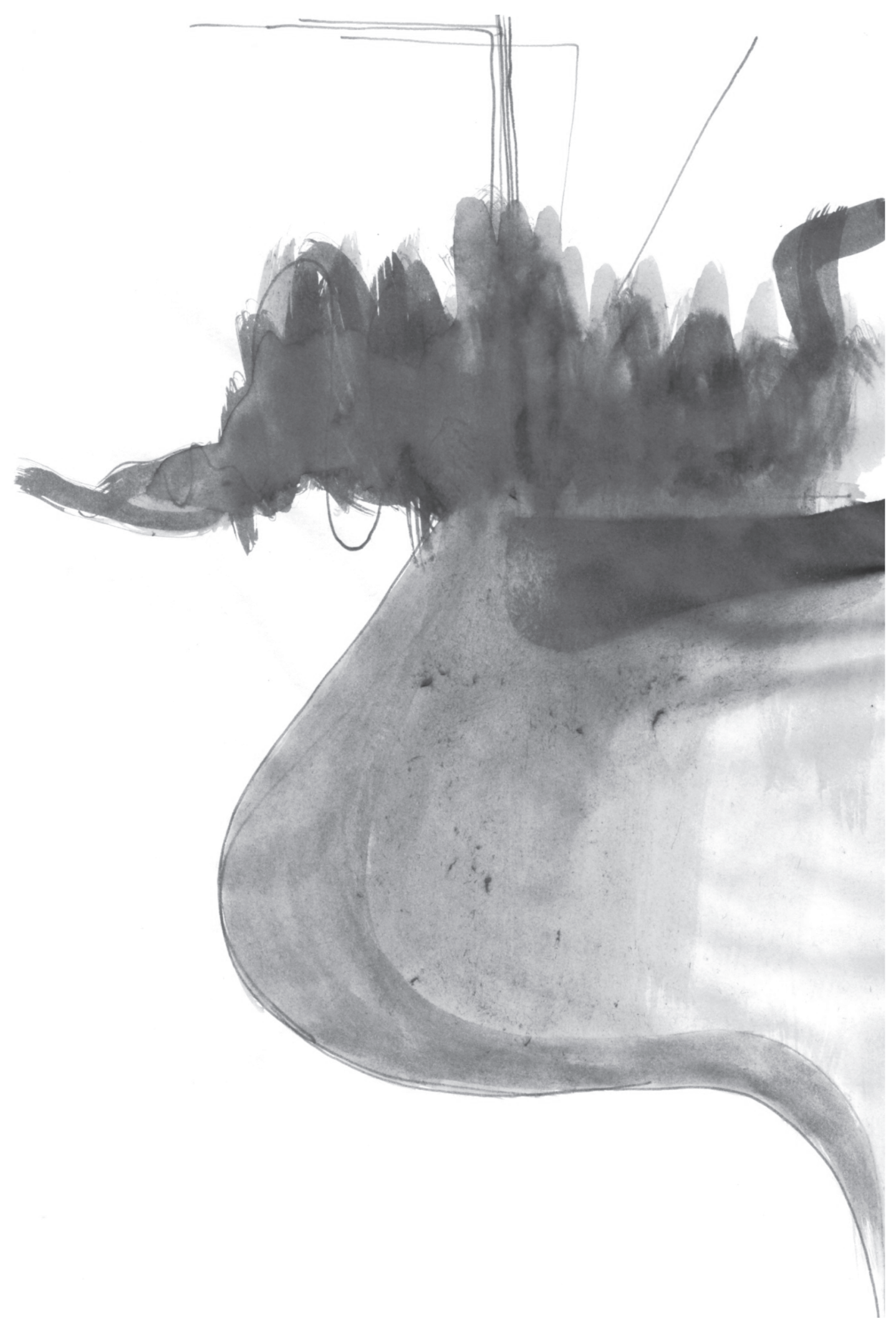

